Article

\title{
Balancing Socio-Ecological Risks, Politics, and Identity: Sustainability in Minnesota's Copper-Nickel-Precious Metal Mining Debate
}

\author{
Ryan D. Bergstrom * (1) and Afton Clarke-Sather (1) \\ Program of Geography, College of Liberal Arts, University of Minnesota, Duluth, MN 55812, USA; \\ afton@d.umn.edu \\ * Correspondence: rbergstr@d.umn.edu;
}

Received: 12 November 2020; Accepted: 7 December 2020; Published: 9 December 2020

\begin{abstract}
In the northeastern corner of Minnesota, two of the state's most iconic symbols, mining and pristine wilderness, are on a collision course. The Duluth Complex, considered by many to be the world's largest undeveloped deposit of copper-nickel and precious metals, is the site of mining proposals for several controversial mines. Proponents suggest that mining can be accomplished in an environmentally benign manner, and in the process create nearly 1000 jobs and $\$ 500$ million in economic benefits annually. Opponents counter that the tourism and recreation industries already provide nearly 18,000 jobs and bring over $\$ 900$ million in economic benefits annually, and that mining will permanently impair the regions environment. Thus, the copper-nickel and precious metal mining debate has become highly polarized, and serves as an ideal example of how people address national and global sustainability issues at local and regional scales. This study examines this polarization through a Q-sort analysis of subjectivities of residents of the state of Minnesota. Results suggest that partisanship is a strong predictor of attitudes towards mining, and that the strongest differences between respondents were not based on perceptions comparing jobs and the environment, the typical partisan divide, but rather on respondents' perceived identity with relation to the mining industry or water resources.
\end{abstract}

Keywords: copper-nickel mining; sustainability; Minnesota; perceptions; partisan politics

\section{Introduction}

In the northeastern corner of Minnesota, two of the state's most iconic symbols, mining and pristine wilderness, are on a collision course. At the center of the debate is the Duluth Complex, a 1.1 billion year old intrusive component of the Midcontinent Rift System, that is considered by many to be the world's largest undeveloped deposit of copper-nickel and precious metals (Cu-Ni-PGE) $[1,2]$ (Figure 1). Although the region has a long history of iron ore mining, copper-nickel mining is a new type of endeavor, with new economic possibilities and environmental concerns. Proponents suggest that mining can be accomplished in an environmentally benign manner, and in the process create nearly 1000 jobs and $\$ 500$ million in economic benefits annually [3]. Opponents counter that the tourism and recreation industry in the region already provide nearly 18,000 jobs and bring over $\$ 900$ million in economic benefits annually [4], and that mining will permanently impair the regions environment. Of particular concern is the potential impact to the Boundary Waters Canoe Area, the most popular Wilderness Area in the United States, with 250,000 annual visitors [5]. As such, the Cu-Ni-PGE debate and its narrative in northeastern Minnesota follows the traditional discourse of environmental degradation vs. economic stability, or jobs vs. the environment $[6,7]$. 


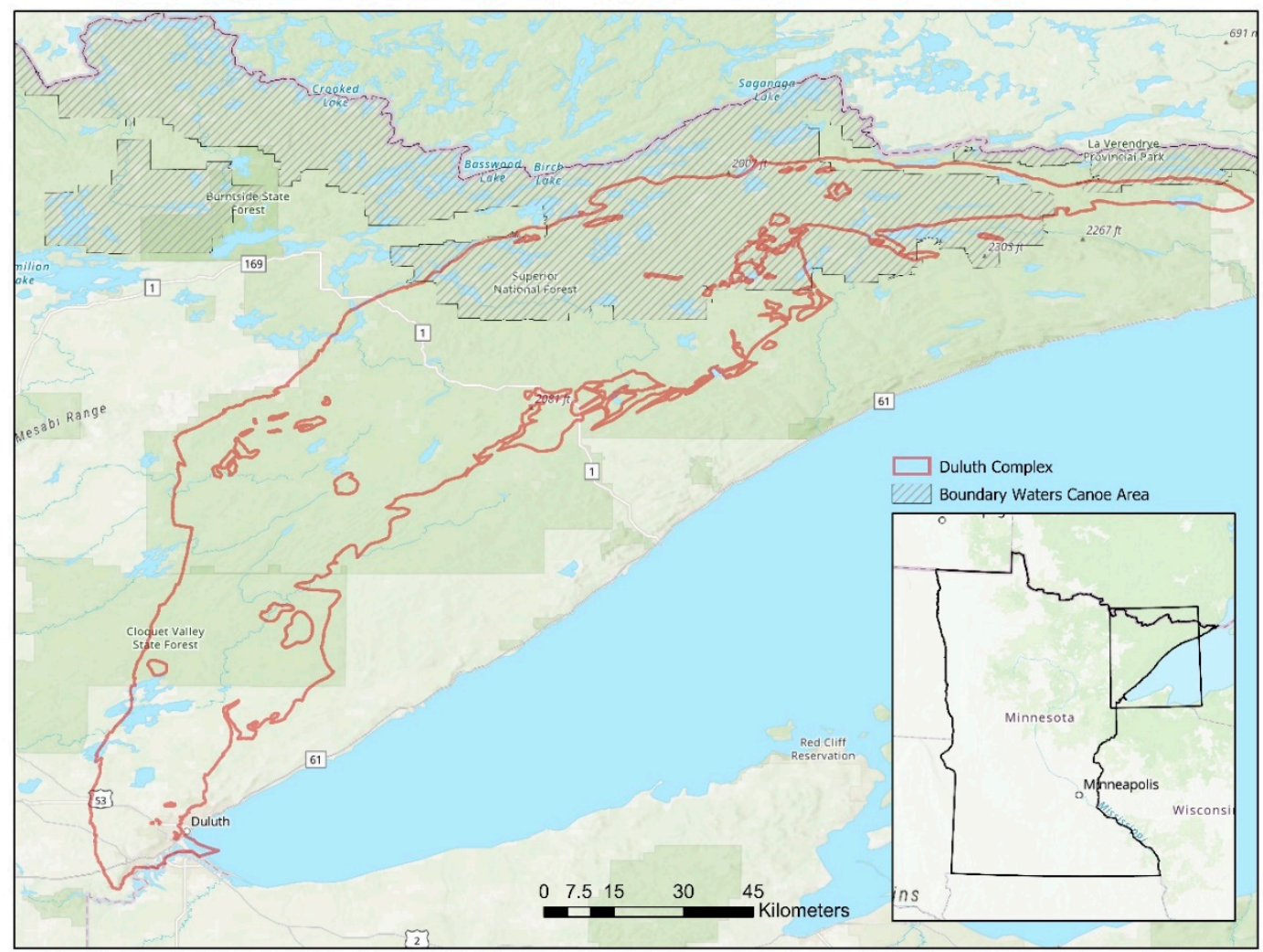

Figure 1. The Duluth Complex of Northeastern Minnesota.

The objective of this study is to determine how a diverse group of residents from across Minnesota conceptualize the sustainability of proposed Cu-Ni-PGE mining, and how those perceptions differ based on geographic, political, and socio-economic contexts using a Q-sort analysis of subjectivities. Sustainability for the purposes of this study is defined as the ability of society to reconcile its social and economic goals within the natural limits of the environment [8]. Sustainability transitions refer to changes to society (technological, economic, ecological, and social) that have the potential to solve "grand societal challenges" [9]. Thought of another way, sustainability transitions involve the transformation of socio-technical systems (i.e., the network of actors, institutions, and materials related to energy, water, transportation systems, etc.) to more sustainable production and consumption modes [10]. At the heart of sustainability transitions are the environmental and sustainability discourses associated with the politics of transition [11]. A better understanding of such discourses are important because they create, reproduce, challenge, and exclude "different representations of the world, thus forming the basis of decisions and actions" [12]. In addition, as Feola and Jaworska [11] suggest, "discourse also matter in framing and identity making and have been shown to influence the level of engagement in collective mobilization for sustainability [13], household or individual pro-environmental action [14], as well as the establishment of collations for or against change [15]". Of particular importance is the idea that societal consensus regarding these challenges have a direct influence on support for or against investments and actions related to them. As such, the conceptual framework of sustainability transitions has been used as a rationale for decision making at a variety of scales [12]. Recent scholarship has added to our overall understanding of sustainability transitions, however, greater attention to the politics and perceptions of these processes is needed [16]. Additionally, the examination of transitions has also been slow to acknowledge where transitions are taking place [17]. The localization of sustainability transitions is important because it is increasingly recognized that structural barriers such as policies and social norms, as well as individual barriers such as values, attitudes, and behaviors, have the potential to significantly promote or hinder successful transitions [18]. As Bridger and Luloff [19] note, "environmental problems, natural and human resource endowments, 
levels of economic and social development, and physical and climatic conditions", that is local context, are critical for successful sustainability transitions.

It is critically important to understand stakeholder perceptions related to the sustainability of natural resource extraction as support and opposition differ based on how communities individually and collectively respond to opportunities and threats associated with proposed activities [20]. One of the largest challenges faced by communities, states or regions rich in natural resources is how to balance economic opportunities against adverse environmental impacts. Decision makers and stakeholders must balance current needs against future risk, a balancing act at the center sustainable development [21]. Decision making in this instance is defined as the varied tools and techniques used by those in power to make decisions [22], or rather, how people make choices given numerous, often times conflicting, alternatives [23]. While regions that are proximate to mining activities often experience the most direct environmental and economic impacts, decision making, and thus control over such projects, most often occurs at sub-national or national level jurisdictions [20], in this case primarily the state-level. Simultaneously, the amount of control stakeholders perceive to have over decision making directly influences their acceptance (or obstruction) of mining projects. This is important because a better understanding of community motivators and agencies and institutions responsible for decision making may help promote sustainability goals at a variety of scales.

Although the literature pertaining to the economic and ecological sustainability of resource extraction are substantial, the perception of these impacts by stakeholders at the local or regional level is under-examined in the literature [24,25]. As such, the knowledge gained from this research will add to the scholarly body related to community perceptions on the sustainability of natural resource extraction [26,27], and thus may prove beneficial to decision makers who must facilitate planning approaches that are sustainable for all stakeholders [28]. Specifically, this study will improve our understanding of stakeholder motivations for supporting and opposing resource extraction enterprises by comparing how individuals balance socio-ecological and environmental risks of proposed mining activities [28]. Lastly, this study will contribute to our understanding of how the sustainability of resource-dependent places connects to larger-scale social (cultural, economic, and political) and environmental processes [29], including sense of place and place attachment [30,31], and governance processes and trust, all of which move beyond the traditional jobs vs. the environment discourse prevalent in resource extraction debates.

\subsection{Resource Extraction in Northeastern Minnesota}

Northeastern Minnesota has featured ferrous (iron) mining since the early 1880s, and mining operations have brought profound changes to local communities, economies, and the natural environment. Since 1884, over 400 mines have extracted millions of metric tons of iron ore throughout the region [32]. However, the region has also been plagued by boom and bust cycles that are typical of resource extraction activities tied to global markets. In 1979, iron ore mining was at its peak in Minnesota, with over 16,000 miners employed. Three years later, due to shifts in global demand, nearly 80 percent of miners were jobless, and out-migration from the region was eclipsing 1 percent annually [33]. While jobs have slowly returned, the cycle continues to repeat itself with collapses in 2001, 2009, and 2016 [34-36]. Despite the boom and bust nature of the industry, mining remains a dominant force in the region, accounting for 30 percent of its GDP (\$3 billion annually) [36]. In addition to mining, tourism brings in an estimated six million visitors to the region, who are drawn to its state and national parks [37]. The largest draw among these is the Boundary Waters Canoe Area (BWCA), consisting of over one million acres featuring interconnected lakes and rivers, accessible only by canoe. The BWCA is one of the most pristine Wilderness Areas in the country, and also one of the most visited, with over 250,000 annual visitors [38]. Tourism and recreation employs over 18,000 in northern Minnesota [39], and generate nearly $\$ 1$ billion annually [40].

Despite the significance of iron ore mining and tourism, the region as a whole remains well behind the rest of the state economically. Poverty rates in St. Louis County, the largest in terms of population, 
are nearly double the state average, while individual cities are far higher [41]. Thus, because of the volatility of the regions three primary industries (mining, tourism, and timber production), two of which are tied to global markets, there has been on-going recognition for some time that economic diversification is critical to long-term sustainability.

\subsection{Copper-Nickel and Precious Metal Mining in Minnesota}

The potential for copper-nickel mining in Northeastern Minnesota has been known since the late 1800s (Figure 2), but these minerals were not exploited as iron mining sustained northern Minnesota. In 1966, the International Nickel Company, Inc. (INCO) was the first company granted copper-nickel mineral leases in the state, and in 1974, INCO filed for permits with the U.S. Forest Service to mine along the South Kawishiwi River, near the southern border of the BWCA. The proposal was met by fierce opposition from then Governor Wendell Anderson, who was concerned with the project's impacts on the BWCA [42]. The Minnesota Environmental Quality Council (EQC) soon developed a policy that required environmental, social, and economic impact studies on all proposed copper-nickel projects, as well as a moratorium on mining until a regional assessment could be completed. That assessment, the Minnesota Regional Copper-Nickel Study [43], found that copper-nickel mining had the potential to meet or exceed existing environmental guidelines, create over 2000 new jobs, and produce over $\$ 50$ billion in profits. However, falling mineral prices, combined with the expense of extracting low-grade ore and public concern over environmental impacts, precluded mining at the time.

Through the 1980s and 1990s, the prospect of copper-nickel mining in northern Minnesota waned, but renewed interest in the early 2000s, primarily through two companies, Polymet and Twin Metals, reignited the mining debate. Polymet's Northmet site is located on an abandoned taconite plant leased from U.S. Steel, and in 2005, Polymet began the environmental review process to mine non-ferrous minerals. In 2009, the Draft Environmental Impact Statement was deemed by the Environmental Protection Agency, "Unsatisfactory-Inadequate". In June 2015, a Final EIS was issued, and the Minnesota Department of Natural Resources determined the proposed Northmet project was adequate, clearing the way for Polymet to begin applying for mining permits through the state.

In January 2018, the Minnesota DNR granted Polymet a draft permit to mine, as well as permits for water appropriations, public water works, and endangered species permits [44]. In addition, the Minnesota DNR approved a $\$ 1$ billion "financial assurance" plan that was intended to protect the region and the state against potential future environmental degradation [2]. However, in January of 2020, just as Polymet was set to finalize the necessary permits to mine, an appellate ruling blocked three permits from the Minnesota DNR, setting the stage for a further appeal with the Minnesota Supreme Court [45]. Simultaneously, a district court began a complicated hearing involving the suppression of information and procedural irregularities by the Minnesota Pollution Control Agency and the Environmental Protection Agency, and their handling of written comments by concerned scientists [46].

Twin Metals Minnesota, a subsidiary of Chilean firm Antofagasta, has proposed a \$2.8 billion mine that would be considerably larger than the Polymet operation, and would be located just a quarter-mile from the BWCA, at the headwaters of the Rainy River that flows into Voyageurs National Park [47]. The mineral leases for the proposed mining site were brought for renewal in 2012 from the Bureau of Land Management (BLM), who eventually declined the renewal. Simultaneously the Obama Administration withdrew nearly 250,000 acres of land from the Superior National Forest from eligibility for mineral leases for a period of two years while environmental assessment could be conducted. Environmentalists had hoped that the results from the environmental studies would place a moratorium on mining for years to come, however, in 2017, the Department of the Interior, under the Trump Administration, renewed the mineral leases that were rescinded, and ended the environmental review [44].

For iron mining communities in the region, still feeling the impacts of the last bust in 2016, news of the Polymet Mining permits was seen as a "Victory for Iron Families" [2]. According to Polymet, the project will create 500 direct jobs during the construction phase, and 260 jobs during the operational 
phase, with the majority of employees hired from the region. These jobs will bring in $\$ 231$ million per year in wages and rents, and \$322 million in direct output from the value of the extracted minerals, as well as $\$ 80$ million annually in federal, state and local taxes.

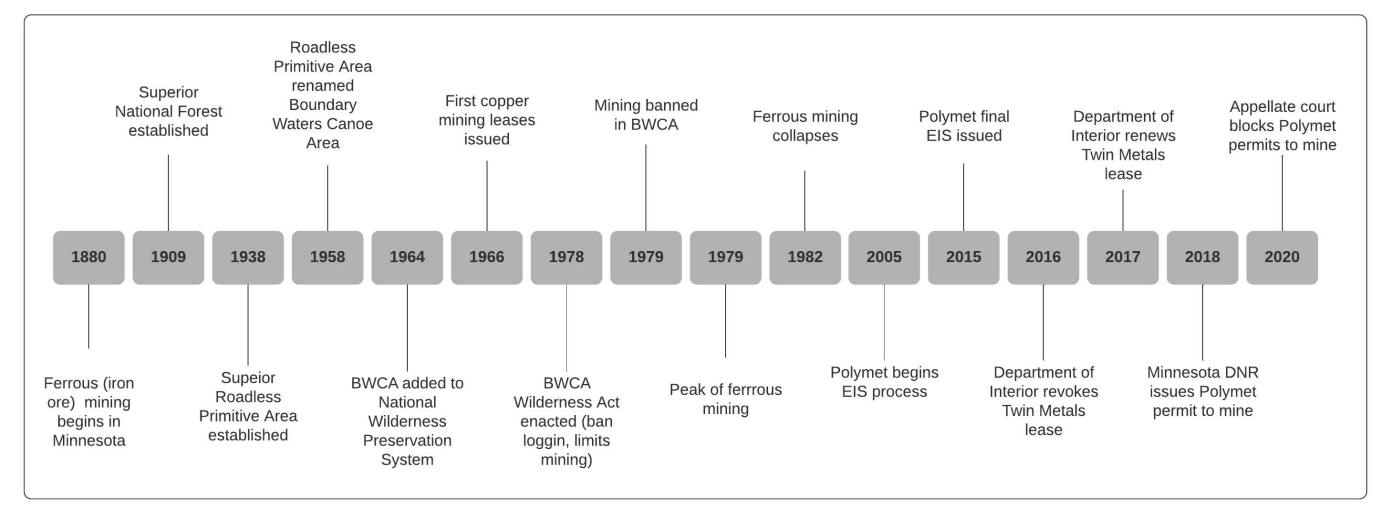

Figure 2. Timeline of Mining in northeastern Minnesota.

One of the largest concerns for both projects is the impact they will have on water and ecological resources. Of particular concern is that similar projects across the globe have caused environmental damage that has cost taxpayers billions of dollar in remediation costs [2]. Twin Metals site, is located in the watershed of the BWCA, and the potential for pollution is a prime concern. Although Polymet's mine and processing sites would not affect the BWCA, they would drain to the St. Louis River, which flows into Lake Superior. The Fond du Lac Band of Lake Superior Chippewa, has raised concerns that pollution in the St. Louis River will impact their efforts to restore native sturgeon populations and wild rice, both of which are culturally and economically important [2]. Further, nearly 2000 acres of Minnesota Biological Survey Sites of High Biodiversity Significance, and nearly 700 acres of "imperiled" or "vulnerable" native plant communities would be threatened or lost, while 11 state-listed "threatened" plant species would be directly impacted. Lastly, the Canadian Lynx, a federally listed wildlife species, and four state-listed species (gray wolf, eastern heater vole, wood turtle, and yellow rail) would be impacted through habitat loss or fragmentation.

\subsection{Ecological Sustainability of Mining}

The ecological impact of mineral extraction varies widely based the geographic and geologic context of the mineral deposit, the methods employed to extract the mineral, the monitoring controls instituted during active mining, and the remediation and reclamation procedures put in place post-extraction. Ecological impacts associated with mineral extraction impact both terrestrial and aquatic ecosystems, and are often irreversible. One of the primary concerns for opponents to copper-nickel-precious metal mining is the potential threat of acid mine drainage. When sulfide minerals (i.e., pyrite) are exposed to oxygen, water, and bacteria (weathering), they generate acidic environments $[48,49]$ through the production of sulfuric acid [50]. Once this sulfuric solution is released into the environment, it often leeches heavy metals from rocks. Not only do such contaminated waters exhibit high heavy metal and sulfuric concentrations, which have immediate short-term consequences, but they also have extreme longevity in most instances [51]. The most serious impacts occur via changes to hydroecological systems, the transformation and contamination of soils and hydrological systems, and the pollution of the atmosphere $[52,53]$. Compounding the issue of sulfide mining and acid mine drainage for northern Minnesota, is that the vast majority of ecological impacts associated with such mining have thus far occurred on arid or semi-arid regions such as the U.S. Southwest [50], and Spain (see [51,53]), which are vastly different from the humid continental climates of Minnesota with pronounced precipitation events.

In contrast to iron deposits mined in northern Minnesota for generations, the copper and nickel found in the northern Minnesota is bound to sulfur in rock, and is thus considered a sulfide mineral. The presence of sulfide minerals (non-ferrous), such as pyrite (FeS2), has the potential to generate a 
significant amount of acidic runoff, and release toxic chemicals including arsenic, asbestos, cadmium, lead, and mercury into the environment $[50,54]$. Sulfide mining has an extensive history of ecological degradation. One survey of 25 operating hard rock mines in the United States found that 85 percent had not met their surface water standards established by an environmental impact assessment, while 93 percent failed to meet their ground water standards [55]. Of particular concern to Minnesotans, especially tribal groups in the state is wild rice (zizania palustris), also known locally as manoomin, a marsh grass that is found in shallow aquatic environments of North America, that is a particularly important aspect of Native American diet, culture and economy in the Great Lakes region. The concern over wild rice is that it has been found to be particularly sensitive to sulfate that enters water bodies in which it grows [56,57]. Beginning in the 1940s, researchers began to realize wild rice grew best in low-sulfate environments, and as such, the Minnesota Pollution Control Agency (MPCA) established a standard of $10 \mathrm{ppm}$ for sulfate in water bodies in the hopes of protecting wild rice and the people who relied upon it [58].

\subsection{Stakeholder Perceptions of Sustainability in Mining}

Perceptions of the sustainability of the mining industry has been increasingly polarized [26,59], especially because of the industry's complexity and its vast array of stakeholders [60]. Thus, in order to reduce conflict between mining operations and local stakeholders, it is critical for mining companies and decision-makers to understand perceptions of any proposed or on-going activities at both the local and sub-national scales [26,27]. Because the extraction of natural resources forces decision makers and stakeholders to make challenging decisions based on individual perceptions and expectations of proposed projects $[28,61]$, it is critical to understand the factors that influence those perceptions as such understanding may help groups facilitate planning approaches that are sustainable for all stakeholders [28].

Numerous studies have examined risk perceptions as they relate to natural hazards [62], and more recently climate change $[63,64]$. However, fewer studies examine the perception of risk associated with the extraction of natural resources. The studies that do exist focus primarily on oil and gas development, with the limited number of studies related to mining focused on specific geographic regions, minerals, or impacts. Our goal in this review is to highlight how past studies have focused on environment vs. economy dichotomies, and may have in the process missed opportunities to explain varied responses to natural resource extraction such as individual and collective identities, and trust in not only the mining process, but the decision making process as well.

Conventional wisdom holds that, not unlike other resource dependent regions, stakeholders in Minnesota are divided between those supporting the economic benefits of mining and those concerned about its environmental impacts. While the mining industry in Minnesota supports over 50,000 jobs and contributes nearly $\$ 3$ billion to the state's economy annually, a number of sustainability related economic, social, and environmental challenges associated with it require trade-offs [65]. First, from the perspective of sustaining natural capital, mining is inherently unsustainable due to the finite supply of resources available, and the environmental impacts associated with extraction [66]. Second, from an economic capital perspective, in many instances, the distribution of economic gains from mining among stakeholders is uneven [67]. Finally, from the perspective of sustaining social capital, it has been suggested that the extraction of natural resources often comes at the cost of compromised human rights, lost livelihoods, and diminished cultural cohesiveness [68]. As such, conflicts related to mining activities are often between resource developers and community stakeholders [69,70], and stem from conflicting interests between local needs and extra-local decision making [71].

\subsection{Socio-Economic Sustainability of Mining}

While ample attention has been given to the ecological sustainability of mining, the social and economic dimension of mining are less well understood [72]. Scholars across numerous disciplines have examined the so-called "resource curse", or the idea that resource abundance equates to negative 
long term economic growth, for the past half-century (see [73-75]. At the same time there exists only a handful of studies that focus on how mining operations impact local economies directly [76]. The socio-economic impacts associated with extractive industries vary considerably over spatial and temporal scales, and are predicated upon local and regional demographics, and public policies designed to minimize public costs [77]. When speaking on the proposed Constantine Mineral Resources project in the Chilkat Valley of southeastern Alaska, Powers and Powers [77] suggested that "no one can say with certainty what impacts will be observed should the project be developed." However, research and observations from similar circumstances in other communities indicate that some or all of the following impacts are likely. First, the higher average wages that extractive workers receive is often offset by a lack of corresponding increases in other sectors of the economy. Second, contrary to popular belief, extractive projects are often correlated with increases in long term unemployment rates, poverty rates, out-migration, lower health, and lower educational attainment. Finally, that the boom-bust and transient nature of extractive industries corresponds with increased substance abuse, increased violence, the undermining of local culture and traditions, and increased conflict between residents.

Furthering the idea that the socio-economic impacts of resource extraction vary considerably over space and time, Gibson and Klinck [78] found that while extractive industries in northern Canada resulted in overall higher wages for rural areas, remoteness and the cyclical nature of the industry resulted in high preponderances of behavioral changes such as drug abuse and alcoholism. Loayza and Rigonlini [79] found that resource-dependent communities in Peru had lower poverty rates, higher per capita incomes, but simultaneously had higher inequalities between local residents as well-educated, higher-paid immigrants displaced community natives. Elsewhere, Haggerty et al. [80] conclude that long-term oil and gas production negatively impacted per capita income, crime, and education rates in the interior U.S. West. In an in-depth review of the existing literature, Deller and Schriber [76] suggest that resource dependent regions have higher population growth rates, high incomes, and fewer individuals below the poverty line. However, because of the boom-bust nature of the industry, the positive economic benefits gained during boom periods are far outweighed by the negative economic conditions during the busts. Further, because of the increase in poverty-levels that accompany rises in per capita income, there exists a widening of economic inequality. Lastly, because the modern extractive industry is so intricately tied to global markets, any instability at the global level will have profound impacts at the local level. This is confirmed by Cust and Poelhekke [81], who suggest that resource extraction has the potential to lead to decreases in housing affordability and availability, places increased demands on municipal infrastructure, and leads to overall concerns related to community well-being.

Conversely, other studies suggest that resource extraction can lead to positive socio-economic effects. When examining the natural gas industry, Weber [82] found that for every $\$ 1$ million of gas produced, 2.35 jobs were created, for an overall employment growth rate of 1.5 percent. At the same time, Feyrer et al. [83] found that for each million dollars of new production, $\$ 80,000$ of local wages, and $\$ 132,000$ in royalties and business income were generated, and that approximately two-thirds of increases persist for up to two-years. In Sweden, Moritz et al. [84] found a positive relationship between increases in extractive industry employment and positive changes in employee numbers of other industries, most notably the service sector. While in Australia, Kotey and Rolfe [85] found that not only do extractive regions have higher incomes, but that income is more equitably distributed with more of the workforce employed in technical occupations that are often higher paying.

\subsection{Social Identity, Process, Governance and Trust}

Beyond environmental and economic risks, we argue that stakeholders' perceptions of the sustainability of natural resource extraction may also be predicated upon issues related to social identity, understanding of mining processes, governance and trust. An individual's attitude towards environmental, social, and economic sustainability challenges are often predicated upon one's sense of place or place attachment [30]. The rationale for this is that individual and group identity is based upon, 
and at times is dependent upon, the shared values and feelings associated with a particular place [31]. One of the primary factors that influence environmental attitudes, perceptions, and behaviors, are based on the bond between humans and a place, commonly known as attachment to place, or place identity. Place identity also has the potential to moderate residents' perceptions of risk. This is particularly important because those with strong place attachment often are unable to identify with conditions that may put those places at risk, while those with low place attachment are better able to disassociate themselves and acknowledge the negative consequences associated with such risk [86]. That is to say, that an individual's sense of place or place attachment have the ability to mediate or moderate their perceptions of risk to that place.

Further, while environmental and economic concerns may dominate discussion of mine decision making, procedural concerns also play an important role. In particular, procedural fairness is based on the idea that community members must feel they have a voice in the decision making process [87].

In response to community calls for increased shares of benefits, with simultaneous reductions in risk, the concept of social license to operate (SLO) was introduced in the late 1990s [88-92]. SLO includes both formal administrative and informal social components. While formal and administrative licensing and permitting exists to protect environmental assets adjacent to proposed mining operations, they are no longer seen as sufficient to cover social and economic impacts to local communities [90,91,93], and as such, communities are reliant upon non-regulatory means of accountability [94]. At its most basic level, SLO implies approval and acceptance of proposed and ongoing resource extraction operations by local communities $[88,91]$. Thus, SLO's are about relationship-building between communities and extractive companies [95].

Community trust suggests that extractive companies will act on the community's behalf, while confidence in governance suggests that existing legal considerations are adequate in protecting local assets. Of particular importance in this regard is the community confidence that regulatory agencies have the ability to hold companies accountable for environmental impacts [96].

\section{Materials and Methods}

This study utilized the Q Method, a mixed methods approach that combines qualitative and quantitative methods to provide a systematic appraisal of subjectivity [97-100]. The Q-method was selected for this study because it excels in identifying unexpected convergences in opinion in cases of highly polarized environmental debate in ways that traditional survey instruments or qualitative methods cannot. Data was gathered at the University of Minnesota Driven to Discovery (D2D) Research Facility at the Minnesota State Fairgrounds (St. Paul, MN, USA), a facility that allows researchers to conduct studies with the general public. The location of the D2D facility allows studies to interact with a broad swath of Minnesota's population, as the Minnesota State Fair receives over 2 million visitors with diverse background from across the state annually. Research was conducted on 24 August 2018 (Friday) between 9 a.m. and 2 p.m. Participants were recruited from all participants who entered the building and were over the age of 18 . Of these 116 participants chose to take part in the study. No characteristics were used to exclude participants, and the sample was not selected based on any demographic variables. As shown in Table 1, the demographic attributes of our participants are not representative of the state of Minnesota, and thus our results should not be extrapolated to understand larger trends throughout the state. In general, respondents were skewed democratic, were Caucasian/White, earned more than $\$ 75,000$, had at least some level of college education, came from the Health Care and Education industries, and resided in metro or micropolitan areas. The Q-method was chosen as it differs from other quantitative methods, such as surveys, that attempt to measure variance in views based on socio-economic and demographic characteristics. Instead, the Q Method identifies shared views and beliefs about a discourse, and is particularly useful when examining highly complex societal problems [101]. In this study we did gather socio-economic data on our participants, but only applied that data to our analysis after the Q-method had been completed. In short, we used socio-economic data to explain our findings from the Q-method. The $\mathrm{Q}$ Method requires that participants sort a series 
of statements related to a discourse from their highest to lowest level of agreement under a specific set of conditions. Once participants have ranked each statement, factor analysis is utilized to reveal patterns and associations, with each pattern representing a social "perspective" or "narrative" [102]. Traditionally, the Q Method is based on five processes: discourse identification, concourse development, $\mathrm{Q}$ set development, the $\mathrm{Q}$ sort, and finally, $\mathrm{Q}$ factor analysis. In this case we have connected the shared perspectives identified through the Q-sort method to existing demographic data (Table 1) as an additional stage of analysis.

Table 1. Respondent Demographics n $=116$.

\begin{tabular}{|c|c|c|c|c|c|c|}
\hline $\begin{array}{l}\text { Gender } \\
\text { (count) }\end{array}$ & Female 44 & Male 72 & & & & \\
\hline Age & $\begin{array}{l}18-101 \\
\text { (range) }\end{array}$ & $\begin{array}{l}\text { Average } 54 \\
\quad \text { (all) }\end{array}$ & & & & \\
\hline $\begin{array}{l}\text { Political } \\
\text { Affiliation }\end{array}$ & $\begin{array}{c}\text { Republication } \\
19\end{array}$ & Democrat 45 & $\begin{array}{l}\text { Independent } \\
31\end{array}$ & Other 6 & & $\begin{array}{c}\text { No Response } \\
15\end{array}$ \\
\hline $\begin{array}{l}\text { Household } \\
\text { Income }\end{array}$ & $\$ 0-25,999: 1$ & $\begin{array}{c}\$ 26,000-51,999: \\
16\end{array}$ & $\begin{array}{l}\$ 52,000-74,999: \\
8\end{array}$ & $\begin{array}{l}\$ 75,000-99,999: \\
25\end{array}$ & $\begin{array}{l}\text { More than } \\
\$ 100,000: 53\end{array}$ & $\begin{array}{c}\text { No Response: } \\
13\end{array}$ \\
\hline Race/Ethnicity & $\begin{array}{l}\text { Asian/Pacific } \\
\text { Islander: } 2\end{array}$ & $\begin{array}{l}\text { Black/African } \\
\text { American: } 2\end{array}$ & $\begin{array}{c}\text { Hispanic/Latino: } \\
0\end{array}$ & $\begin{array}{l}\text { Indian/Native } \\
\text { American: } 2\end{array}$ & $\begin{array}{l}\text { White/Caucasian: } \\
110\end{array}$ & \\
\hline $\begin{array}{l}\text { Education } \\
\text { Completed }\end{array}$ & $\begin{array}{l}\text { High School } \\
\text { Graduate: } 7\end{array}$ & $\begin{array}{c}\text { Some } \\
\text { College-no } \\
\text { Degree: } 17\end{array}$ & $\begin{array}{l}\text { Associates } \\
\text { Degree: } 11\end{array}$ & $\begin{array}{l}\text { Bachelor's } \\
\text { Degree: } 51\end{array}$ & $\begin{array}{l}\text { Master's } \\
\text { Degree: } 21\end{array}$ & $\begin{array}{l}\text { Doctoral } \\
\text { Degree: } 9\end{array}$ \\
\hline Occupation & $\begin{array}{l}\text { Health/Social } \\
\text { Services: } 30\end{array}$ & Education: 23 & $\begin{array}{l}\text { Manufacturing: } \\
16\end{array}$ & Agriculture: 6 & $\begin{array}{l}\text { Construction: } \\
6\end{array}$ & $\begin{array}{l}\text { Finance/Real } \\
\text { Estate: } 6\end{array}$ \\
\hline
\end{tabular}

\subsection{Defining the Concourse}

The Q-method begins by developing a set of statements, known as a concourse, which represents the breadth of discourse of the research topic. The source of these statements varies, including qualitative interviews [97,100], and secondary materials such as newspaper articles [97,103]. A critical aspect of defining the concourse is ensuring that the statement used are representative of topic, however, ambiguity is not a concern as participants infer their own interpretation of the statements [104].

The concourse for this study was collected based on the content analysis of newspaper articles from the Duluth News Tribune dated between 2006 and 2016 (Bergstrom, forthcoming). A total of 122 quotes related to copper-nickel and precious metal mining were obtained that reflect the breadth of issues surrounding the debate. This list was then further reduced to 16 statements, the ' $Q$ Set' (Table 2), based on their relationship to nine themes (economics, the environment, process, risk, identity, laws and regulations, tribal relationships, water resources, and education). These nine themes were later reduced to the five dimensions of sustainability discussed below. It should be noted that these five dimensions reflect the current context within northern Minnesota, and as such are likely not applicable to other regions. That being said, they can serve as a general guide for decision makers of other regions in their pursuit of better understanding stakeholder conceptualizations of contentious mining projects.

The number of statements included in the $Q$ set varies considerably based on the amount of time allotted for participant sorting, but studies typically range from 30 and 80 statements [99]. However, for this study, 16 statements were chosen based on the environmental and temporal constraints imposed by the research facility. Subject recruitment called for reducing the amount of time per participant to around five minutes, and our pre-testing indicated that this could be accomplished with 16 statements. While most studies rely upon a smaller number of participants sorting a larger number of statements, we utilized a smaller number of statements to ease subject recruitment, allowing a much larger sample size than is typical of Q-method studies. Making the study accessible was particularly important because while $Q$ method approaches generally rely upon respondents who are deeply engaged with the issues, this approach allowed us to gather the opinions of a broader swath of the 
population, including many who are less engaged with the issue of mining, and thus potentially bring less polarizing opinions.

Table 2. Concourse Statements.

\begin{tabular}{|c|c|c|c|c|c|c|}
\hline $\begin{array}{l}\text { Statement } \\
\text { Number }\end{array}$ & Statement & 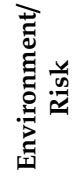 & 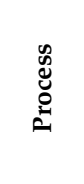 & 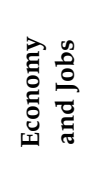 & 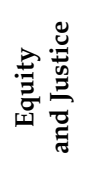 & 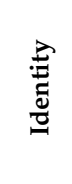 \\
\hline 1 & We all value clean water, and we all want good jobs & $x$ & & $x$ & & \\
\hline 2 & $\begin{array}{l}\text { There is no amount of financial assurance to match the } \\
\text { financial risk of sulfide mining }\end{array}$ & $\mathrm{x}$ & & & & \\
\hline 3 & $\begin{array}{c}\text { Even with the best technology, all mining operations have } \\
\text { environmental concerns }\end{array}$ & $\mathrm{x}$ & & & & \\
\hline 4 & $\begin{array}{l}\text { Most Minnesotans are not familiar with mining's } \\
\text { environmental track record }\end{array}$ & $\mathrm{x}$ & & & & \\
\hline 5 & The long-term risk of mining is too difficult to quantify & $x$ & & & & \\
\hline 6 & $\begin{array}{l}\text { The cleanest processing technology and best practices will } \\
\text { be used }\end{array}$ & $\mathrm{x}$ & $\mathrm{x}$ & & & \\
\hline 7 & $\begin{array}{c}\text { The current laws we have do a great job of protecting } \\
\text { the environment }\end{array}$ & $\mathrm{x}$ & $\mathrm{x}$ & & & \\
\hline 8 & $\begin{array}{l}\text { Mining companies have worked with tribes and communities } \\
\text { to adhere to strict water regulations }\end{array}$ & & $\mathrm{x}$ & & $\mathrm{x}$ & \\
\hline 9 & Copper mining enriches few and costs many & & & $x$ & $\mathrm{x}$ & \\
\hline 10 & $\begin{array}{l}\text { Jobs will be filled by individuals relocating to the area, } \\
\text { not locals }\end{array}$ & & & $\mathrm{x}$ & & \\
\hline 11 & Tourism jobs don't pay a livable wage & & & $x$ & & \\
\hline 12 & We need mining jobs for the economy of Minnesota & & & $x$ & & \\
\hline 13 & $\begin{array}{l}\text { If we don't mine, companies will target third-world nations } \\
\text { without environmental standards }\end{array}$ & & & & $\mathrm{x}$ & \\
\hline 14 & Sulfide mining threatens Minnesota's water-it's way of life & $x$ & & & & $x$ \\
\hline 15 & Northeast Minnesota is the mining industry & & & & & $x$ \\
\hline \multirow[t]{3}{*}{16} & We are selling our land to the highest bidder & & & & $x$ & $x$ \\
\hline & Average z-score statements in dimension & 0.14 & -0.30 & 0.03 & -0.25 & 0.001 \\
\hline & Average Stdev of statements in dimension & 0.89 & 0.82 & 0.79 & 0.91 & 1.17 \\
\hline
\end{tabular}

\subsection{The $Q$ Sort}

A total of 116 individuals participated in the study, each of whom was assigned a random participant identifier to tie their Q Sort to separately gathered demographic data. No identifying information on participants was gathered. The 16 statements that constituted the concourse (Q Set) were printed onto numbered cards (one statement per card), and given to the participant. Participants were briefed on the nature of the study, including its focus on copper-nickel and precious metal mining, and were instructed to read through each statement and then rank them on a continuum from those they agree with the most at one end, to those they agree with the least on the other. The continuum was indexed from (-3) most disagree, to (+3) most agree, for subsequent analysis. Once participants had ranked each statement, they placed each statement on the Q-sort grid number side up, although most participants ranked and placed statement simultaneously. Participants were then asked a brief set of demographic questions, and the researchers photographed the Q-sort grid and the demographic profile. Each sort was entered into Microsoft Excel based on their unique identifier, with each of the 16 statements aligning with one of the index values $(-3$ to +3$)$. These were then tied to participant demographic data that was also entered into Microsoft Excel. It should be noted, that although it is common to conduct qualitative interviews with participants after each sort [97], due to time and 
physical space limitations, this was omitted from this study. As such, groupings of respondents are drawn solely from quantitative analysis.

\subsection{Q Factor Analysis}

Q-factor analysis was conducted using the online Ken-Q web suite [105]. Q-factor analysis can be considered in four steps: the generation of a correlation matrix, factor extraction, factor rotation, and generation of factor loadings for each statement. The generation of a correlation matrix is relatively straightforward. For factor extraction, there are several approaches to deciding on the final number of factors to be selected in a Q-sort. An eigen-value threshold of 1 is often proposed, however, due to the large number of respondents, all factors had eigen values above 1. A second approach to selecting variables to keep involves visually inspecting a bar graph of eigen values to select when a notable break occurs. This is the approach that we have taken in this study. We tested the effect on factor loadings of changing the numbers of factors, and concluded that individual factors remained relatively stable up to five variables. However, the loadings of statements associated with groups beyond 2 changed significantly when more than five variables were introduced. For this reason, five factors were retained for rotation. These factors were rotated using a varimax rotation. Loadings for each factor were created for each sort, and sorts were flagged for the factor to which they were most similar. These flagged factors represented groups as discussed below.

Based on the loadings for each factor, individual sorts were flagged based on its association with factors at above a $95 \%$ confidence level, and were assigned to a group based upon that factor. We allowed the presence of bipolar factors (i.e., sorts that register most strongly as a mirror-image of one of the existing sorts). These flagged sorts were then used to generate composite sorts for each factor, and z-scores (average sort values) for each statement based on the sorts flagged for that factor. It is worth considering for a moment the relationship between groups and factors. Every single response from a participant in the form of a sort generated a loading for each of the five factors identified. In most cases they loaded strongly with one factor at the 95\% confidence level, however only 96 of the 116 sorts were strongly associated and thus sorted into a group. From these groups the average z-score (average sort position) of each statement was taken, and those statements that were different from other groups (distinguishing statements) were identified. The relative ranking of statements by these groups are then taken to represent the subjectivity associated with the factor from which they were generated. In summary, every sort has a loading for each factor, but only some sorts belong to the group associated with that factor.

In addition to considering groups, we also analyzed the z-scores and level of agreement for each statement to see which statements shared relative similar, or dissimilar levels of agreement. In addition to listing statements, each statement was coded as fitting into one or more themes that we have identified as dimensions of sustainability in this region: environment and risk, decision-making process, economy and jobs, equity and justice, and identity. Many, but not all statements were identified as being related to more than one dimension of sustainability.

To better understand which respondents fit into each subjective grouping, we gathered demographic data and regressed factor loadings for each factor against demographic variables. One regression was conducted for each factor loading. The sample for the regression included all participants, not only those who were flagged for a particular factor. Potential explanatory variables that we kept included income, age, education level, and partisan affiliation (Democrat, Republican, Independent, Other, and Prefer not answer). Independents were selected as the default category for partisan affiliation because their average factor loading was nearest to zero. These demographic variables were only applied after groups had already been established, and intended to understand whether demographic variables could explain patterns in subjectivity that we had identified. 


\section{Results}

\subsection{Characteristics of Groups and Factors}

Through our analysis we sorted respondents into the following five groups. This sorting explained $66 \%$ of the variance in the sample. When interpreting the meaning of the number of respondents assigned to groups two issues should be considered. First, respondents were only flagged to a group if their sorts $p$-value associated with statement was less than 0.05, as a result, 20 sorts were not flagged to any group (96 sorts were flagged to a group). All sorts had loadings for each factor, but for grouping purposes only those significantly associated with a factor were chosen. Thus group 1 represents those sorts most emblematic of factor 1 . Second, our demographic data showed that this sample was not demographically representative of the population of the state of Minnesota as a whole, and as such, these statements should be taken as a guide to the variety of opinion that exists. That is, too much should not be drawn from the relative number of people associated with each sort. Table 3 presents the statements and average sort position from $-3-3$ (z-score) and the rank of from 1 (most agreement) to 16 (least agreement) for each group.

Table 3. Concourse Statements and Z-Scores.

\begin{tabular}{ccccccccccc}
\hline $\begin{array}{c}\text { Statement } \\
\text { Number }\end{array}$ & $\begin{array}{c}\text { Group 1 } \\
\text { Z-Score }\end{array}$ & $\begin{array}{c}\text { Group 1 } \\
\text { Rank }\end{array}$ & $\begin{array}{c}\text { Group 2 } \\
\text { Z-Score }\end{array}$ & $\begin{array}{c}\text { Group 2 } \\
\text { Rank }\end{array}$ & $\begin{array}{c}\text { Group 3 } \\
\text { Z-Score }\end{array}$ & $\begin{array}{c}\text { Group 3 } \\
\text { Rank }\end{array}$ & $\begin{array}{c}\text { Group 4 } \\
\text { Z-Score }\end{array}$ & $\begin{array}{c}\text { Group 4 } \\
\text { Rank }\end{array}$ & $\begin{array}{c}\text { Group 5 } \\
\text { Z-Score }\end{array}$ & $\begin{array}{c}\text { Group 5 } \\
\text { Rank }\end{array}$ \\
\hline 1 & 0.46 & 6 & 1.86 & 1 & 2 & 1 & 1.51 & 2 & 1.81 \\
2 & 0.86 & 4 & -0.84 & 12 & -0.14 & 8 & 1.19 & 3 & -0.07 & 9 \\
3 & 1.31 & 1 & 0.75 & 5 & 1.38 & 2 & -0.43 & 11 & 0.09 & 8 \\
4 & 0.43 & 7 & 0.91 & 4 & -1.06 & 13 & -0.25 & 10 & 1.63 & 2 \\
5 & 0.42 & 8 & -0.46 & 10 & -1.28 & 15 & 0.83 & 4 & -0.24 & 10 \\
6 & -1.55 & 15 & 0.47 & 7 & 0.77 & 4 & 0.53 & 5 & -0.3 & 12 \\
7 & -1.36 & 14 & -0.28 & 9 & -0.72 & 12 & 0.19 & 6 & 0.19 & 6 \\
8 & -1.55 & 16 & -0.02 & 8 & -1.11 & 14 & -0.23 & 9 & 0.52 & 5 \\
9 & 0.7 & 5 & -1.01 & 13 & -0.46 & 11 & 0.18 & 7 & -1.3 & 15 \\
10 & -0.01 & 9 & -1.27 & 15 & -0.16 & 9 & -0.23 & 8 & -0.48 & 13 \\
11 & -0.49 & 12 & -1.09 & 14 & 0.64 & 5 & -1.61 & 16 & 0.13 & 7 \\
12 & -1.09 & 13 & 1.08 & 3 & 1.02 & 3 & -1.2 & 15 & -0.29 & 11 \\
13 & -0.2 & 10 & 0.67 & 6 & -1.37 & 16 & -0.99 & 14 & 0.55 \\
14 & 1.22 & 3 & -0.56 & 11 & -0.19 & 10 & 1.95 & 1 & -0.48 \\
15 & -0.45 & 11 & 1.16 & 2 & 0.08 & 7 & -0.89 & 13 & -2.39 \\
16 & 1.31 & 2 & -1.37 & 16 & 0.58 & 6 & -0.56 & 12 & 14 \\
\hline
\end{tabular}

\subsubsection{Group 1: Environmental Concerns and Water Identity}

Group 1 had the largest number of respondents assigned to it (42), and accounted for 24 percent of the variance in the sample. This group is characterized by a strong skepticism about environmental impacts of mining and the decision process related to mining, relatively neutral opinions on jobs-related statements, and strong opinions on water-related identity issues. However, this was also a bipolar group, with four respondents flagged for negative association, suggesting they more closely resembled a negative value for this group than a positive value for any other group.

Distinguishing statements for this group included high levels of agreement with Statement 16, "We are selling our land to the highest bidder," and Statement 14, "Mining threatens Minnesota's water, its way of life". Critically, Statement 14 reflects both environmental concerns and identity themes. This group was also characterized by high levels of disagreement with process related statements, most notably Statements 6-8, all of which were distinguishing statements for Group 1 based on low levels of agreement. This combination of distrust in process-related statements, combined with high agreement with statements of risk, distinguish this group. Critically, Group 1 displayed the lowest level of agreement with Statement 1, "We all value clean water, we all want good jobs", although they still evaluated the statement slightly positively. The lower level of agreement made this a distinguishing statement at the 99 percent confidence level. Our interpretation of relatively lower rates of agreement with Statement 1, in conjunction with low levels of trust in process-related statements and neutral positions on jobs statements, is that this group shows lower trust that advocates of mining truly value clean water. 


\subsubsection{Group 2: Supportive of Jobs and Mining Identity}

Group 2 had the second largest number of respondents assigned to it (30), and accounted for 19 percent of the variance in the sample. In contrast to Group 1, this group had no negative factor loadings, and was characterized by a strong focus on jobs, relatively neutral positions on environmental and process concerns, and strong emphasis on mining-related identity issues. The primary distinguishing feature of this group was an emphasis on jobs. The strongest levels of agreement were with Statements 12 "We need mining jobs for the economy of Minnesota," and 1 "We all value clean water, and we all want good jobs", although neither was flagged as a statistically distinguishing statement. Interestingly, this group showed strong disagreement, at greater than a 99 percent confidence level, with Statement 10, "Tourism jobs don't pay a livable wage", indicating that this position focuses on valuing all jobs. This result is somewhat surprising, because the terms of debate around mining in northeastern Minnesota often contrast what are perceived as lower paying and less stable tourism jobs with higher paying mining jobs. The strongest distinguishing statement associated with this grouping was related to the identity focused question 15, "Northeast Minnesota is the mining industry", for which Group 2 had both the highest composite score, and is also a distinguishing statement for this group. This indicates that for the two largest groupings, identity statements are among the largest points of difference.

\subsubsection{Group 3: Resigned to Environmental Impacts of Mining}

Group 3 had 10 respondents assigned to it, and accounted for eight percent of variation in the sample. This group is distinguished by its concern for jobs, relative neutrality on questions of identity, awareness of environmental impacts from mining, paired with a moderate level of distrust in the mining process. Jobs concerns filled two of the three spots for strongest level of agreement for this group, however again, at levels that did not make them distinguishing statements. However, agreement with Statement 10, "Tourism Jobs do not pay a livable wage" was a distinguishing feature of this group at the 95 percent confidence level. This group also showed the highest level of agreement with this statement, indicating that it valued mining jobs in particular. The composite sort for this group assigns a relatively neutral position to the identity statements 14 "Sulfide mining threatens Minnesota's water- it's way of life" and 15 "Northeast Minnesota is the mining industry" that were particularly divisive in groups 1 and 2. This group also showed relatively higher awareness of the environmental risks of mining, showing agreement with Statement 3, "Even with the best technology, all mining operations have environmental concerns", and disagreement with Statement 5, "The long term risk of mining is too difficult to quantify". Lastly, this group showed some level of distrust in process, with process-based Statements $7 \& 8$ being distinguishing statements for their negative loadings. In general, this group appears to acknowledge the risks of mining, but remains supportive because of the jobs created.

\subsubsection{Group 4: The Risk Adverse}

Grouping 4 accounted for eight percent of the sample variance, and had eight sorts flagged, of which three were flagged for negative values. This grouping is distinguished by a strong emphasis on risk-related statements, showing the highest level of agreement with statements 14 "Sulfide Mining Threatens Minnesota water-its way of life" and 5 "the long-term risks of sulfide mining are too difficult to quantify". Group 4 was also characterized by strong disagreement with statement 11, "Tourism jobs don't pay a living wage", though other jobs-related questions remained relatively neutral.

\subsubsection{Group 5: Process Orientation Low Levels of Identity}

Group 5 accounted for seven percent of the variance in the sample, and had six flagged sorts, one of which was flagged for negative values. This group was characterized by relatively high levels of trust in the environmental decision-making process and the lowest level of agreement of any group with identity statements 14 and 15 . This group showed the strongest levels of agreement out of all groups with statement 8 , "Mining companies have worked with tribes and communities to adhere 
to strict water regulations", which was a distinguishing statement at the 95 percent confidence level. The other distinguishing characteristic associated with this group is the low level of agreement with both identity statements. Group 5 showed the lowest level of agreement of all groups with the statement 15 , "Northeast Minnesota is the mining industry", but also received its second lowest z-scores for the statement 14, "Sulfide mining threatens Minnesota's identity, its way of life."

\subsection{Agreements between Groups on Statements}

Table 3 lists each of the statements used in this analysis, alongside the z-score (average composite score) and rank for each group, the z-score and rank for all statements, and the standard deviation of z-score between groups and standard deviation rank (from least to most agreement). The most profound surprise from this analysis was that no consensus statements were found between all respondents. While we anticipated that respondents would find consensus on Statement 1, "We all value clean water, we all want good jobs", the statement was ranked first or second among all groups with the exception of Group 1, which ranked it sixth. Further, Statement 1 had the second highest level of agreement, behind Statement 10, however, that statement had an average z-score near zero, indicating a lack of strong opinion about the issue.

Table 2 also presents averages z-scores of statements by dimension of sustainability. Z-scores can be thought of as average position ratings from -3 to 3 for a statement in a sort. There are two ways to look at these average $z$-scores. First, the average z-score indicates whether respondents held positive or negative views of these statements, with negative z-score indicating more negative view. Second, the standard deviation of z-scores can be examined, to see whether there is agreement between groups for a given dimension of sustainability. Across groups, process and equity statements had negative average z-scores, indicating that across groups, opinion of the decision-making process and equity associated with mining development in Northeastern Minnesota is low. Notably, the statement, "Mining companies have worked with tribes and communities to adhere to strict water regulations", received positive z-scores from only one group (Group 5, discussed below). Even those groups holding positive views of mining from both an economic and identity perspective (groups $2 \& 3$ ) appear to have low agreement with the process surrounding the environmental decision making. Identity and job-related statements had average $\mathrm{z}$-scores near zero, and environment-related statements had slightly positive $z$-scores. These averages are not exclusive, so if a statement was coded in multiple dimensions, it was considered in both statements average z-score. We also considered the standard deviation in z-scores between groups, which measures levels of disagreement between groups surrounding statements.

The greatest levels of disagreement were around statements related to identity, (standard deviation of 1.17). We identified three primary identity related statements, "Sulfide mining threatens Minnesota's water-it's way of life", "Northeast Minnesota is the Mining industry", and "We are selling our land and water to the highest bidder". These three statements had the highest standard deviation between groups of any statements. This is also interesting in light of the near zero average z-score for these statements, indicating that groups were polarized on these statements. The standard deviations for other dimensions were more closely packed, ranging from 0.79 for job-related statements, to 0.91 for statements concerning equity. In summary, process and equity statements were viewed the most negatively, but statements concerning identity showed the greatest levels of variation.

\subsection{Demographic Variabless Influencing Factor Loadings}

To estimate what demographic variables might impact statement groupings, a regression analysis was conducted to compare socio-economic variables with each of the five factor groupings. Socio-economic variables included income (estimated as midpoint income from groupings), age, education attainment (measured in years), and partisan affiliation. Earlier analysis also examined occupational sector, urban/rural status, and time of residence, which through exploratory data analysis did not appear to have a strong relationship with groupings. These variables were used to estimate the loading for each factor from individual respondents' q-sort. Our analysis did not predict which 
factor each individual would be most strongly associated with. One regression was conducted for each of the five factors. Table 4 presents the results of this analysis. It is clear from these results that partisan affiliation is strongly associated with Factors 1, 2, and 4. Further, these regressions results, while displaying relatively low adjusted $\mathrm{R}^{2}$ values, had F-statistics indicating that they were significant at least at the 95 percent confidence value ( 99 percent for Factors 1\&2). However, Factors 3 and 5 do not have meaningful relationships with any variables, and had F statistics that were not significant at the 95 percent confidence interval. Outside of partisan affiliation none of our demographic variables proved to be predictors of factor loadings. This is itself an interesting result, as years of education, age, and income proved to have no influence on factor loadings.

Table 4. Factor Analysis.

\begin{tabular}{|c|c|c|c|c|c|}
\hline $\begin{array}{l}\text { Factor (Named by } \\
\text { Corresponding } \\
\text { Group) }\end{array}$ & $\begin{array}{c}\text { Factor } 1 \\
\text { Environmental } \\
\text { Concerns and } \\
\text { Water Identity }\end{array}$ & $\begin{array}{c}\text { Factor } 2 \\
\text { Supportive of } \\
\text { Jobs and Mining } \\
\text { Identity }\end{array}$ & $\begin{array}{l}\text { Factor } 3 \text { Resigned } \\
\text { to Environmental } \\
\text { Impacts of Mining }\end{array}$ & $\begin{array}{l}\text { Factor } 4 \text { the } \\
\text { Risk Adverse }\end{array}$ & $\begin{array}{c}\text { Factor } 5 \text { Process } \\
\text { Orientation Low } \\
\text { Levels of Identity }\end{array}$ \\
\hline \multirow{2}{*}{$\begin{array}{l}\text { Income (coefficient) } \\
\text { (standard error) }\end{array}$} & 0.0002 & 0.0004 & -0.0003 & 0.0005 & 0.0001 \\
\hline & 0.001 & 0.001 & 0.0004 & 0.0004 & 0.0004 \\
\hline \multirow[t]{2}{*}{ Years of Education } & -0.012 & -0.006 & -0.005 & -0.009 & 0.01 \\
\hline & 0.017 & 0.016 & 0.012 & 0.012 & 0.011 \\
\hline \multirow[t]{2}{*}{$\begin{array}{l}\text { Partisan Lean } \\
\text { Democrat }\end{array}$} & $0.262 * * *$ & $-0.214^{* *}$ & -0.005 & $0.187^{* * *}$ & -0.069 \\
\hline & 0.095 & 0.087 & 66 & 0.066 & 0.058 \\
\hline \multirow[t]{2}{*}{ Other } & -0.166 & -0.112 & 0.134 & 0.175 & 0.145 \\
\hline & 0.187 & 0.171 & 0.129 & 0.13 & 0.115 \\
\hline \multirow[t]{2}{*}{ Prefer not to answer } & -0.0197 & 0.195 & -0.013 & 0.077 & 0.122 \\
\hline & 0.154 & 0.141 & 0.106 & 0.107 & 0.095 \\
\hline \multirow[t]{2}{*}{ Republican } & $-0.263^{* *}$ & 0.225 & -0.026 & -0.068 & 0.023 \\
\hline & 0.117 & 0.107 & 0.081 & 0.081 & 0.072 \\
\hline \multirow[t]{2}{*}{ Age } & 0.117 & 0.107 & 0.081 & 0.081 & 0.072 \\
\hline & 0.002 & 0.002 & 0.002 & 0.002 & 0.002 \\
\hline \multirow[t]{2}{*}{ Constant } & 0.077 & $0.329 *$ & $0.323^{* *}$ & -0.187 & 0.002 \\
\hline & 0.188 & 0.171 & 0.13 & 0.13 & 0.115 \\
\hline Observations & 101 & 101 & 101 & 101 & 101 \\
\hline R2 & 0.262 & 0.236 & 0.048 & 0.155 & 0.087 \\
\hline Adjusted R2 & 0.207 & 0.179 & -0.024 & 0.091 & 0.019 \\
\hline $\begin{array}{l}\text { Residual Std. Error } \\
\qquad(\mathrm{df}=93)\end{array}$ & 0.384 & 0.351 & 0.265 & 0.266 & 0.235 \\
\hline $\begin{array}{l}\text { F Statistics } \\
\left(\mathrm{df}=7^{\prime} ; 93\right)\end{array}$ & $4.724^{* * *}$ & $4.109^{* * *}$ & 0.664 & $2.438 * *$ & 1.273 \\
\hline
\end{tabular}

Note: ${ }^{*} p<0.1 ;{ }^{* *} p<0.05 ;{ }^{* * *} p<0.01$.

Partisan lean was the variable that was most clearly associated with Factors 1, 2 \& 4. 'Independent' affiliation was chosen as a default for all analyses. Factor 1 was positively associated with Democratic Party affiliation and negatively associated with Republican Party affiliation. All else being equal, Democratic identifying respondent would be expected to have a loading of 0.339 for Factor 1 , while a Republican identifying respondent would be expected to have a loading of -0.186 . Factor 2 shows a similar but inverse relationship, with Republicans expected to have a higher loading. It is important to remember that factor loadings were determined independently of partisan identifications, and analysis of partisan affiliation was only applied after conducting the q-method analysis. Thus it appears that partisan affiliation predicts respondents' subjectivity with respect to sustainability and mining. It should be emphasized that these associations are not predictive of the population of the state of Minnesota as a whole, but rather reflect the sample that we have selected.

\section{Discussion}

The results of this study have found that the first and largest group of respondents in our sample is generally skeptical of the environmental risks of mining, skeptical of the mining process, and relatively indifferent to concerns about jobs. It should be emphasized that this was drawn from a non-representative sample, and should not be extrapolated to the state of Minnesota as a whole. 
The second group is strongly supportive of jobs and relatively indifferent to environmental and decision-making process concerns. However, this group differs from common interpretations of the jobs-environment debate because of a relative positive view of tourism jobs, which previous studies have shown to often be looked down on by advocates of mining [106-108]. That said, the strongest difference between these two groupings rests on questions of identity. Group 1 and 2 both rated identity questions strongly, but in opposing ways. Group 1 strongly identified threats to Minnesota's water as its 'way of life', while Group 2 identified strongly that "northeast Minnesota is the mining industry". While Groups 1 and 2 differed in their attitudes towards the environment, decision-making processes, and jobs, these differences were not as significant as differences in attitudes towards identity-related statements. Although Groups 1 and 2 represented the largest portions of our sample population, this population is not representative of the state of Minnesota, and thus the numerical strength of each group should not be taken as representative of the population of the state of Minnesota.

Groups 3 through 5 were more complex. As was the case with Group 2, Group 3 was concerned with jobs, but was relatively neutral in their identity with the region. While this group also showed concern for the environmental impacts of mining, our general interpretation is that this group was concerned about jobs, and rather than downplaying environmental impacts, viewed them as a necessary trade-off for economic growth. Group 4 shared some similarities to Group 1, but with heightened scores for questions concerning risk and uncertainty. This group was also strongly supportive of tourism jobs, while relatively neutral on other jobs questions. Group 5 was distinguished as having relatively stronger trust in the decision making process, but having very low identity-related z-scores, indicating a lack of strong opinions about identity.

Our regression results indicated that partisanship is a strong predictor of attitudes towards mining. Democratic Party affiliation predicts higher loadings for Factors 1 and 4 at the 99 percent confidence level, and lower loadings for Factor 2 at the 95\% confidence level. Republican Party affiliation predicts lower loadings for Factor 1, and higher loadings for Factor 2, both at the 95\% confidence level. Although these models had relatively low adjusted R2 values, regressions for Factors 1 and 2, and 4 were significant at the 99\% and 95\% confidence levels respectively. Loadings for Factors 3 and 5 were not associated with any demographic variables, and regression models for these factors were not significant. Although both factors have relatively large, though statistically not significant, coefficients associated with a political affiliation of 'other', suggest that these factors may be associated with those with political identification separate from the mainstream parties. It is worth noting that regression tests for partisan affiliation were applied ex post facto to groupings, so partisan affiliation did not influence how groups were sorted. Further, age, income and education levels were not significant predictors in any model. In summary, Factors (1\&4), concerned with environmental impacts and risks are associated with Democratic affiliations, while those showing a greater concern for jobs (Factor 2) is associated with Republican party affiliation. However, the strongest differences rating statements for these groups is not based on statements comparing jobs and the environment, but rather on statements that concern identity. Group 1, which is predicted by Democratic Party affiliation, is more likely to strongly identify Minnesota's water as part of its 'way of life', while those in Group 2, which is predicted by Republican Party affiliation, rank the statement 'Northeast Minnesota is the Mining industry' more strongly. This finding is of interest because the mining areas of Northeastern Minnesota were historically among the most democratic leaning in the state. These partisan results were unexpected to us, as we did not expect opinion on this issue to break in quite so partisan a manner.

\section{Conclusions}

The discourse surrounding the sustainability of natural resource extraction and its impact on local communities is often build around the dichotomy between economic stability and environmental degradation [6], and often pits resource developers and community or regional stakeholders against each other [43,44]. We have used a Q-sort methodology to compare the attitudes of a diverse group of Minnesota residents on the sustainability of copper-nickel and precious metals (Cu-Ni-PGE) mining in 
northeastern Minnesota to determine how their perceptions differed based on geographic, political and socio-economic contexts. Our results indicate that while the traditional jobs vs. the economy narrative is prevalent in northeastern Minnesota, other narratives exist that relate to how stakeholders connect to larger-scale social sustainability processes [11], including sense of place and place attachment [12,13], and governance processes and trust $[14,15]$. A better understanding of how various groups perceive the sustainability of $\mathrm{Cu}-\mathrm{Ni}$-PGE mining is important because it helps move the narrative beyond jobs vs. the environment, to the root causation of motivators to support or oppose mining operations, and thus may facilitate the long-term sustainability of resource-dependent communities.

As has been found with other extractive industries (see [20,91]), respondents perceive the sustainability, risks and benefits associated with Cu-Ni-PGE mining differently, and these differences are often based on one's identity with, and attachment to, the region, its economy, and its environment. As Tuan found [109], some of the primary factors that influence environmental perceptions are based on the bond humans have with place, as well as individuals lived experiences. This attachment to, sense of, and identity with, a particular geographic place are predicated upon emotional, functional, and cognitive interactions with said place. However, those individuals who identify strongly with a place often are unable to identify the conditions that will put those places at risk [86].

In addition, the bonds' one has with a place are not necessarily predicated upon residence in that place, because place attachment may be independent of place identity. This is particularly relevant in northeastern Minnesota, where both the Boundary Waters and Iron Range bring strong associations with wilderness, and industry and labor respectively. As a result, an individual may have a particularly strong attachment to a place due to a past memory or experience, but not have a direct identity associated with that place. Place attachment can also be hierarchical: an individual may have an identity tied to a particular city, which is part of a region, which is part of state, and eventually a nation, all of which contribute to that individual's bond with a place [75]. In the case of Minnesota, places in northeastern Minnesota are often associated with the state as a whole. For many Minnesotans, the harsh climate, dedicated work ethic, and physical environment form the core of their place identity [76-78]. Simultaneously, northeastern Minnesota is also home to several of Minnesota's icon symbols of nature, including the state bird, the loon. For Minnesotans who have lived in the region for generations, their place identity, and thus their attachment to the region, are predicated upon a shared history that built the nation through the extraction of its natural resources, and this identity has been transferred to the state as a whole. On the other hand, for Minnesotans who live outside the region, northern Minnesota is an aggregation of the amenities that draw them to the region, including tourism, recreation, and most notably, the Boundary Waters Canoe Area.

The knowledge gained from this study is important because it provides insights into how individuals perceive a highly contentious debate at the heart of the sustainability discourse. As has been shown in previous studies [13-15], identity making, sense of place, and place attachment influences the level at which individuals engage in sustainability-related issues. In addition, the bonds that individuals have with particular places are one of the primary factors influencing perceptions and behaviors. Because of this, how individuals identify with particular places influences their perception of risk associated with that place. For the respondents of this study, individuals who identify northern Minnesota with abundant freshwater and recreational opportunities are more likely to oppose activities that could disrupt that identity. At the same time, those who identify northern Minnesota as the utilitarian landscape of the past are more likely to support activities that reinforce that perception. It is telling that the most significant divergence in opinion between groups, as measured by the standard deviation of z-scores between statements, occurred around issues of place identity.

While place attachment and place identity are critical components in determining how individuals perceive the $\mathrm{Cu}-\mathrm{Ni}$-PGE mining debate in northeastern Minnesota, those perceptions are also directly related to the informal social components of social license to operate (SLO), or rather, the relationship and trust between the general public and extractive companies. Although formal SLO's are rarely issued, their informal acceptance is driven in large part by local context. Because of the importance 
placed on local community perceptions related to extractive activities, and because communities are critical arbiters due to their close proximity to projects local stakeholders have become powerful actors in the decision making process. Thus, individual perceptions have a direct influence on supporting or opposing proposed actions (in this case precious metal mining), and the societal consensus that emerges related to such topics often is used as a rationale for decision making at a variety of scales. One method by which individual perceptions have the potential to influence policy decisions is through the National Environmental Policy Act (NEPA). NEPA requires federal agencies to conduct environmental impact statements (EIS) on actions that could impact the environment, and includes a 45-day period whereby public comments are accepted and must subsequently be responded to in order for projects to be approved. Over its 15-year environmental review process, the Polymet project in northeastern Minnesota received nearly 100,000 public comments [110]. While there is no legal mandate for public comments to influence decision making on proposed projects, the sheer number of responses during the Polymet EIS reinforce the gravity of this debate in the minds of Minnesotans and their desire to partake in both the formal and informal social license to operate processes.

It is acknowledged that this study has its limitations. From a methodological standpoint, the study is unconventional in that it uses a smaller number of statements (16 versus traditional 30-80), due to environmental (space) and temporal ( 5 min per respondent) constraints imposed by the research facility. However, while the study relied upon a smaller number of statements, we were able to incorporate a much larger number of respondents than typical q-method studies. In doing so, we were able to gather the perceptions of a broader swath of the population, including many who were less familiar with the issue of mining, and thus bring less polarizing opinions. In relation to the results, although this study represents a small subset of Minnesota residents, it does represent the perceptions of a socio-economically diverse group of individuals as it relates to a highly contentious environmental, economic, and political discourse. Because of this, the lessons learned from this study may be beneficial to other stakeholders and decision makers who must grapple with balancing economic viability and environmental integrity.

Because of the limitations provided above, additional research is warranted. This includes collecting additional responses during multiple dates at the Minnesota State Fair, as well as at other more localized public events across the state (i.e., county fairs, farmers markets, craft fairs, etc.). Data collected during such events will provide not only deeper insights into respondent conceptualizations, but also provide the opportunity for longitudinal comparisons. This is particularly important given the highly dynamic nature of this debate, and the ever-changing political environment.

Whether an individual identifies northeastern Minnesota as the bastion of pristine water or natural resource extraction, this identity, often coupled with partisan leanings, is the best predictor of support for mining operations. In the end, the realization that highly contentious topics such as proposed $\mathrm{Cu}$-Ni-PGE mining are thought of as more than simply a jobs vs. the environment debate is helpful as it provides an additional lens with which decision makers can communicate and connect with stakeholders, and ultimately result in more sustainable mining projects that are mutually beneficial. As such, the discourse surrounding precious metal mining in northeastern Minnesota adds to our overall understanding of sustainability transitions, particularly the realization that local context (identity and politics), play a fundamental role in places where global sustainability transitions are being debated and acted upon at a local scale. This realization, coupled with the understanding that structural (policies and social norms) and individual behaviors (values, attitudes, and behaviors) have the potential to influence decision making a variety of scales, and thus promote or hinder sustainability transitions.

Author Contributions: Co-authors and R.D.B. and A.C.-S. were both responsible for survey design and implementation, manuscript edits and revisions. R.D.B. was responsible for literature review and conclusions, while A.C.-S. was responsible for the methods and results sections, including all statistical analysis. All authors have read and agreed to the published version of the manuscript.

Funding: This research received no external funding. 
Conflicts of Interest: The authors declare no conflict of interest

\section{References}

1. Richards, J. Explore Minnesota-Copper Nickel PGEs; Minnesota Department of Natural Resources: St. Paul, MN, USA, 2016; p. 4.

2. McKinney, M.; Marcotty, J. On the Iron Range, New Hopes and New Anxieties: Permit Approvals for Polymet Open a New Chapter in an Old Struggle. St. Tribune 2018. Available online: https://www.startribune.com/ on-the-iron-range-new-hopes-and-new-anxieties/500211461/ (accessed on 8 December 2020).

3. Skurla, J. NorthMet Economic Impact 2011 Update: Economic Impact of Polymet's Northmet Project on St. Louis County, Minnesota; University of Minnesota Duluth: Duluth, MN, USA, 2012; p. 40.

4. Tourism and the Economy. Available online: https://mn.gov/tourism-industry/research/tourism-and-theeconomy.jsp (accessed on 1 June 2020).

5. Minnesota Department of Natural Resources. Final Environmental Impact Statement (FEIS) NorthMet Mining Project and Land Exchange; Minnesota Department of Natural Resources: St. Paul, MN, USA, 2015; p. 3576.

6. Forgrave, R. In Northern Minnesota, Two Economies Square Off: Mining vs. Wilderness. The New York Times, 2017. Available online: https:/www.nytimes.com/2017/10/12/magazine/in-northern-minnesota-twoeconomies-square-off-mining-vs-wilderness.html (accessed on 8 December 2020).

7. Goodstein, E. The Trade-Off Myth: Fact And Fiction About Jobs And The Environment; Island Press: Washington, DC, USA, 1999; ISBN 978-1-59726-930-8.

8. Clark, W.C.; Dickson, N.M. Sustainability science: The emerging research program. Proc. Natl. Acad. Sci. USA 2003, 100, 8059-8061. [CrossRef]

9. Köhler, J.; Geels, F.W.; Kern, F.; Markard, J.; Onsongo, E.; Wieczorek, A.; Alkemade, F.; Avelino, F.; Bergek, A.; Boons, F.; et al. An agenda for sustainability transitions research: State of the art and future directions. Environ. Innov. Soc. Transit. 2019, 31, 1-32. [CrossRef]

10. Markard, J.; Raven, R.; Truffer, B. Sustainability transitions: An emerging field of research and its prospects. Res. Policy 2012, 41, 955-967. [CrossRef]

11. Feola, G.; Jaworska, S. One transition, many transitions? A corpus-based study of societal sustainability transition discourses in four civil society's proposals. Sustain. Sci. 2019, 14, 1643-1656. [CrossRef]

12. Fløttum, K.; Gjesdal, A.M.; Gjerstad, Ø.; Koteyko, N.; Salway, A. Representations of the future in English language blogs on climate change. Glob. Environ. Chang. 2014, 29, 213-222. [CrossRef]

13. Feola, G. Capitalism in sustainability transitions research: Time for a critical turn? Environ. Innov. Soc. Transit. 2020, 35, 241-250. [CrossRef]

14. Pernilla, H.; Karin, B. Transitions on the home front: A story of sustainable living beyond eco-efficiency. Energy Res. Soc. Sci. 2017, 31, 240-248. [CrossRef]

15. Hajer, M.A. Politics on the move: The democratic control of the design of sustainable technologies. Knowl. Policy 1995, 8, 26-39. [CrossRef]

16. Meadowcroft, J. Engaging with the politics of sustainability transitions. Environ. Innov. Soc. Transit. 2011, 1, 70-75. [CrossRef]

17. Coenen, L.; Benneworth, P.; Truffer, B. Toward a spatial perspective on sustainability transitions. Res. Policy 2012, 41, 968-979. [CrossRef]

18. Leiserowitz, A. Climate Change Risk Perception and Policy Preferences: The Role of Affect, Imagery, and Values. Clim. Chang. 2006, 77, 45-72. [CrossRef]

19. Bridger, J.C.; Luloff, A.E. Toward an interactional approach to sustainable community development. J. Rural Stud. 1999, 15, 377-387. [CrossRef]

20. Ladd, A.E. Stakeholder Perceptions of Socioenvironmental Impacts from Unconventional Natural Gas Development and Hydraulic Fracturing in the Haynesville Shale. J. Rural Soc. Sci. 2013, 28, 56-89.

21. Poelzer, G.A.; Ejdemo, T. Too Good to be True? The Expectations and Reality of Mine Development in Pajala, Sweden. Arct. Rev. Law Politics 2018, 9. [CrossRef]

22. Tzeng, G.-H.; Huang, J.-J. Multiple Attribute Decision Making: Methods and Applications; CRC Press: Boca Raton, FL, USA, 2011; ISBN 978-1-4398-6157-8.

23. Edwards, W. The theory of decision making. Psychol. Bull. 1954, 51, 380-417. [CrossRef] 
24. Bec, A.; Moyle, B.D.; McLennan, C.J. Drilling into community perceptions of coal seam gas in Roma, Australia. Extr. Ind. Soc. 2016, 3, 716-726. [CrossRef]

25. Sovacool, B.K. What are we doing here? Analyzing fifteen years of energy scholarship and proposing a social science research agenda. Energy Res. Soc. Sci. 2014, 1, 1-29. [CrossRef]

26. Wang, L.; Awuah-Offei, K.; Que, S.; Yang, W. Eliciting Drivers of Community Perceptions of Mining Projects through Effective Community Engagement. Sustainability 2016, 8, 658. [CrossRef]

27. Walsh, B.; van der Plank, S.; Behrens, P. The effect of community consultation on perceptions of a proposed mine: A case study from southeast Australia. Resour. Policy 2017, 51, 163-171. [CrossRef]

28. Van der Plank, S.; Walsh, B.; Behrens, P. The expected impacts of mining: Stakeholder perceptions of a proposed mineral sands mine in rural Australia. Resour. Policy 2016, 48, 129-136. [CrossRef]

29. Flint, C.; Luloff, A.E. Natural Resource-Based Communities, Risk, and Disaster: An Intersection of Theories. Soc. Nat. Resour. 2005, 18, 399-412. [CrossRef]

30. Masterson, V.; Stedman, R.; Enqvist, J.; Tengö, M.; Giusti, M.; Wahl, D.; Svedin, U. The contribution of sense of place to social-ecological systems research: A review and research agenda. Ecol. Soc. 2017, 22. [CrossRef]

31. Chapin, F.S.; Knapp, C.N. Sense of place: A process for identifying and negotiating potentially contested visions of sustainability. Environ. Sci. Policy 2015, 53, 38-46. [CrossRef]

32. Lass, W.E. Minnesota: A History; W.W. Norton \& Co.: New York, NY, USA, 1998; ISBN 0-393-31971-7.

33. Serrin, W. Recession Silences the Mines of the Minnesota Iron Range. The New York Times, 1992. Section 1. p. 1. Available online: https://www.nytimes.com/1982/08/07/us/recession-silences-the-mines-of-the-minnesotairon-range.html (accessed on 8 December 2020).

34. Power, T.M. The Economic Role of Metal Mining in Minnesota: Past, Present, and Future Minnesota Center for Environmental Advocacy and the Sierra Club; University of Montana: Missoula, MT, USA, 2007; p. 39.

35. Kraker, D. Mine layoffs bring new calls to remake Iron Range economy, but into what? Minnesota Public Radio, 2016.

36. U.S. Geological Survey. Mineral Commodity Summaries 2017; USGS: Washington, DC, USA, 2017.

37. Arrowhead Regional Development Commission. Master Plan: Lake County Mountain Bike Trail System; Arrowhead Regional Development Commission: Duluth, MN, USA, 2016; p. 62.

38. Kittelson, T.; Dunn, L.; Holmes, T.; Morton, P.; Hussain, A. Regional Economic Impacts of Boundary Waters Wilderness Visitors; Conservation Economics Institute: Twin Falls, ID, USA, 2015. Available online: https://recpro.memberclicks.net/assets/Library/Economic_Impact/Boundary_Waters_Economics_ Report-2016.pdf (accessed on 8 December 2020).

39. The Northspan Group, Inc. The Economic Impact of Leisure E Hospitality in IRRRB Service Area; The Northspan Group, Inc.: Duluth, MN, USA, 2015; p. 41.

40. Explore Minnesota Facts \& Figures: Explore Minnesota Tourism. Available online: http://www. exploreminnesota.com/industry-minnesota/research-reports/facts-figures/ (accessed on 26 November 2018).

41. U.S. Census Bureau American Fact Finder. ACS Demographic and Housing Estimates. Available online: https://factfinder.census.gov/faces/nav/jsf/pages/index.xhtml (accessed on 8 December 2020).

42. Kraker PolyMet's Copper-Nickel Mine Rekindles Decades-Old Environmental Debate. Available online: https://www.mprnews.org/story/2013/12/05/polymets-copper-nickel-mine-rekindles-decades-oldenvironmental-debate (accessed on 26 February 2020).

43. Minnesota Environmental Quality Board The Minnesota Regional Copper-Nickel Study, 1976-1979/-Minnesota Legislative Reference Library. Available online: https://mnpals-lrl.primo.exlibrisgroup. com/discovery/openurl?institution=01MNPALS_LRL\&vid=01MNPALS_LRL:LRL\&rft.oclcnum=05579755 (accessed on 26 February 2020).

44. Kraker, D. Four Things that Need to Happen before Polymet Mine's Future Can Be Written. MPR News, 2018. Available online: https://www.mprnews.org/story/2018/08/28/five-things-that-need-to-happen-beforepolymet-copper-mine-future-is-written (accessed on 8 December 2020).

45. Stanley, G. PolyMet Appeals Ruling That Blocked Its Mining Permits. Star Tribune, 2020. Available online: https://www.startribune.com/polymet-appeals-court-ruling-that-blocked-its-miningpermits/567043162/ (accessed on 8 December 2020).

46. Kraker, D. In Court, Environmental Regulators Accused of Suppressing Comments in PolyMet Case. Available online: https://www.mprnews.org/story/2020/01/22/in-court-environmental-regulators-accused-ofsuppressing-comments-in-polymet-case (accessed on 22 January 2020). 
47. Marcotty, J. Defeat for Minnesota Wilderness Protection Means Back to Business for Mining. Star Tribune, 2018. Available online: https://www.startribune.com/defeat-for-minnesota-wilderness-protection-means-backto-business-for-mining/492819691/\#: \{\}:text=The\%20federal\%20government's\%20sudden\%20decision, back $\% 20$ to\%20business\%20as\%20usual. (accessed on 8 December 2020).

48. Johnson, D.B.; Hallberg, K.B. Acid mine drainage remediation options: A review. Sci. Total Environ. 2005, 338, 3-14. [CrossRef]

49. Favas, P.J.C.; Sarkar, S.K.; Rakshit, D.; Venkatachalam, P.; Prasad, M.N.V. Acid Mine Drainages From Abandoned Mines. In Environmental Materials and Waste; Elsevier: Amsterdam, The Netherlands, 2016; pp. 413-462, ISBN 978-0-12-803837-6.

50. Onello, E.; Allert, D.; Bauer, S.; Ipsen, J.; Saracino, M.; Wegerson, K.; Wendland, D.; Pearson, J. Sulfide Mining and Human Health in Minnesota. Minn. Med. 2016, 99, 51-55.

51. Caraballo, M.A.; Macías, F.; Nieto, J.M.; Ayora, C. Long term fluctuations of groundwater mine pollution in a sulfide mining district with dry Mediterranean climate: Implications for water resources management and remediation. Sci. Total Environ. 2016, 539, 427-435. [CrossRef]

52. Helios Rybicka, E. Impact of mining and metallurgical industries on the environment in Poland. Appl. Geochem. 1996, 11, 3-9. [CrossRef]

53. Garcia, G.; Peñas, J.M.; Manteca, J.I. Zn mobility and geochemistry in surface sulfide mining soils from SE Spain. Environ. Res. 2008, 106, 333-339. [CrossRef]

54. Pearson, T.W. Frac Sand Mining and the Disruption of Place, Landscape, and Community in Wisconsin. Hum. Organ. 2016, 75, 47-58. [CrossRef]

55. Pearson, J.; Ipsen, J.; Sutherland, S.; Wegerson, K.; Onello, E. Risks and costs to human health of sulfide-ore mining near the Boundary Waters Canoe Area Wilderness. Hum. Ecol. Risk Assess. Int. J. 2019, 1-12. [CrossRef]

56. Lunn, J. North American Wild Rice Faces Sulfide Toxicity. EOS 2017. [CrossRef]

57. Myrbo, A.; Swain, E.B.; Engstrom, D.R.; Coleman Wasik, J.; Brenner, J.; Dykhuizen Shore, M.; Peters, E.B.; Blaha, G. Sulfide Generated by Sulfate Reduction is a Primary Controller of the Occurrence of Wild Rice (Zizania palustris) in Shallow Aquatic Ecosystems. J. Geophys. Res. Biogeosci. 2017, 122, 2736-2753. [CrossRef]

58. Plain, C. Protecting Wild Rice from Sulfate Pollution-School of Public Health-University of Minnesota. School of Public Health, 2017. Available online: https://www.sph.umn.edu/news/protecting-wild-rice-sulfate-pollution/ (accessed on 8 December 2020).

59. Laurence, D. Establishing a sustainable mining operation: An overview. J. Clean. Prod. 2011, 19, $278-284$. [CrossRef]

60. Mudd, G.M. The Environmental sustainability of mining in Australia: Key mega-trends and looming constraints. Resour. Policy 2010, 35, 98-115. [CrossRef]

61. Lyytimäki, J.; Peltonen, L. Mining through controversies: Public perceptions and the legitimacy of a planned gold mine near a tourist destination. Land Use Policy 2016, 54, 479-486. [CrossRef]

62. Brasier, K.J.; McLaughlin, D.K.; Rhubart, D.; Stedman, R.C.; Filteau, M.R.; Jacquet, J. Research Articles: Risk Perceptions of Natural Gas Development in the Marcellus Shale. Environ. Pract. 2013, 15, 108-122. [CrossRef]

63. Grätz, T. Gold-mining and risk management: A case study from Northern Benin. Ethnos 2003, 68, $192-208$. [CrossRef]

64. Shi, X.; He, F. The Environmental Pollution Perception of Residents in Coal Mining Areas: A Case Study in the Hancheng Mine Area, Shaanxi Province, China. Environ. Manag. 2012, 50, 505-513. [CrossRef]

65. Azapagic, A. Developing a framework for sustainable development indicators for the mining and minerals industry. J. Clean. Prod. 2004, 12, 639-662. [CrossRef]

66. Didyk, V.; Bay-Larsen, I.; Sandersen, H.; Ivanova, L.; Isaeva, L.; Kharitonova, G. Sustainability and Mining: The Case of the Kola Peninsula. In The Will to Drill-Mining in Arctic Communites; Dale, B., Bay-Larsen, I., Skorstad, B., Eds.; Springer International Publishing: Cham, Switzerland, 2018; pp. 103-125. ISBN 978-3-319-62608-6.

67. Eilperin, J. Mining Firm Profits from Public Lands Remain a Mystery, New GAO Study Shows. Washington Post, 2012. Available online: https://www.washingtonpost.com/national/health-science/mining-firmprofits-from-public-lands-remain-a-mystery-new-gao-study-shows/2012/12/11/c3416110-43c1-11e2-8061253bccfc7532_story.html (accessed on 8 December 2020). 
68. Martinez-Alier, J. Mining conflicts, environmental justice, and valuation. J. Hazard. Mater. 2001, 86, $153-170$. [CrossRef]

69. Davis, R.; Franks, D.M. The Costs of Conflict with Local Communities in the Extractive Industry; SR Mining: Santiago, Chile, 2011.

70. Franks, D.M.; Davis, R.; Bebbington, A.J.; Ali, S.H.; Kemp, D.; Scurrah, M. Conflict translates environmental and social risk into business costs. Proc. Natl. Acad. Sci. USA 2014, 111, 7576-7581. [CrossRef] [PubMed]

71. Ballard, C.; Banks, G. Resource Wars: The Anthropology of Mining. Annu. Rev. Anthropol. 2003, 32, $287-313$. [CrossRef]

72. Everingham, J.-A. Towards Social Sustainability of Mining: The Contribution of New Directions in Impact Assessment and Local Governance. Greener Manag. Int. 2007, 57, 91-103. [CrossRef]

73. Robinson, J.A.; Torvik, R.; Verdier, T. Political foundations of the resource curse. J. Dev. Econ. 2006, 79, 447-468. [CrossRef]

74. Humphreys, M.; Sachs, J.; Stiglitz, J.E. Escaping the Resource Curse; Columbia University Press: New York, NY, USA, 2007; ISBN 978-0-231-14196-3.

75. Fleming, D.A.; Measham, T.G.; Paredes, D. Understanding the resource curse (or blessing) across national and regional scales: Theory, empirical challenges and an application. Aust. J. Agric. Resour. Econ. 2015, 59, 624-639. [CrossRef]

76. Deller, S.C.; Schreiber, A. Mining and Community Economic Growth. Rev. Reg. Stud. 2012, 42, 121-141.

77. Power, T.M.; Power, D. The Social Cost of Mining on Rural Communities; Power Consulting: Missoula, MT, USA, 2019; p. 28.

78. Gibson, G.; Klinck, J. Canada's Resilient North: The Impact of Mining on Aboriginal Communities. Pimatisiwin A J. Aborig. Indig. Community Health 2005, 3, 1-26.

79. Loayza, N.; Rigolini, J. The Local Impact of Mining on Poverty and Inequality: Evidence from the Commodity Boom in Peru. World Dev. 2016, 84, 219-234. [CrossRef]

80. Haggerty, J.; Gude, P.H.; Delorey, M.; Rasker, R. Long-term effects of income specialization in oil and gas extraction: The U.S. West, 1980-2011. Energy Econ. 2014, 45, 186-195. [CrossRef]

81. Cust, J.; Poelhekke, S. The Local Economic Impacts of Natural Resource Extraction. Annu. Rev. Resour. Econ. 2015, 7, 251-268. [CrossRef]

82. Weber, J.G. The effects of a natural gas boom on employment and income in Colorado, Texas, and Wyoming. Energy Econ. 2012, 34, 1580-1588. [CrossRef]

83. Feyrer, J.; Mansur, E.T.; Sacerdote, B. Geographic Dispersion of Economic Shocks: Evidence from the Fracking Revolution. Am. Econ. Rev. 2017, 107, 1313-1334. [CrossRef]

84. Moritz, T.; Ejdemo, T.; Söderholm, P.; Wårell, L. The local employment impacts of mining: An econometric analysis of job multipliers in northern Sweden. Miner. Econ. 2017, 30, 53-65. [CrossRef]

85. Kotey, B.; Rolfe, J. Demographic and economic impact of mining on remote communities in Australia. Resour. Policy 2014, 42, 65-72. [CrossRef]

86. Venables, D.; Pidgeon, N.F.; Parkhill, K.A.; Henwood, K.L.; Simmons, P. Living with nuclear power: Sense of place, proximity, and risk perceptions in local host communities. J. Environ. Psychol. 2012, 32, 371-383. [CrossRef]

87. Zhang, A.; Measham, T.G.; Moffat, K. Preconditions for social licence: The importance of information in initial engagement. J. Clean. Prod. 2018, 172, 1559-1566. [CrossRef]

88. Prno, J.; Scott Slocombe, D. Exploring the origins of 'social license to operate' in the mining sector: Perspectives from governance and sustainability theories. Resour. Policy 2012, 37, 346-357. [CrossRef]

89. Prno, J.; Slocombe, D.S. A Systems-Based Conceptual Framework for Assessing the Determinants of a Social License to Operate in the Mining Industry. Environ. Manag. 2014, 53, 672-689. [CrossRef]

90. Prno, J. An analysis of factors leading to the establishment of a social licence to operate in the mining industry. Resour. Policy 2013, 38, 577-590. [CrossRef]

91. Moffat, K.; Zhang, A. The paths to social licence to operate: An integrative model explaining community acceptance of mining. Resour. Policy 2014, 39, 61-70. [CrossRef]

92. Boutilier, R.G.; Thomson, I. Modelling and Measuring the Social License to Operate: Fruits of a Dialogue Between Theory and Practice. Available online: https://socialicense.com/publications.html (accessed on 15 March 2020). 
93. Gunningham, N.; Kagan, R.A.; Thornton, D. Social License and Environmental Protection: Why Businesses Go Beyond Compliance. Law Soc. Inq. 2004, 29, 307-341. [CrossRef]

94. Wright, S.; Bice, S. Beyond social capital: A strategic action fields approach to social licence to operate. Resour. Policy 2017, 52, 284-295. [CrossRef]

95. Mercer-Mapstone, L.; Rifkin, W.; Moffat, K.; Louis, W. Conceptualising the role of dialogue in social licence to operate. Resour. Policy 2017, 54, 137-146. [CrossRef]

96. Zhang, A.; Moffat, K. A balancing act: The role of benefits, impacts and confidence in governance in predicting acceptance of mining in Australia. Resour. Policy 2015, 44, 25-34. [CrossRef]

97. Brown, S.R. A Primer on Q Methodology. Operant Subj. 1993, 6, 91-138.

98. Brown, S.R. Q Methodology and Qualitative Research. Qual. Health Res. 1996, 6, 561-567. [CrossRef]

99. Shinebourne, P. Using Q Method in Qualitative Research. Int. J. Qual. Methods 2009, 8, 93-97. [CrossRef]

100. Barry, J.; Proops, J. Seeking sustainability discourses with Q methodology. Ecol. Econ. 1999, 28, 337-345. [CrossRef]

101. Eden, S.; Donaldson, A.; Walker, G. Structuring subjectivities? Using Q methodology in human geography. Area 2005, 37, 413-422. [CrossRef]

102. Webler, T.; Tuler, S. Four Perspectives on Public Participation Process in Environmental Assessment and Decision Making: Combined Results from 10 Case Studies. Policy Stud. J. 2006, 34, 699-722. [CrossRef]

103. McKeown, B.; Thomas, D.B. Q Methodology; SAGE Publications: Thousand Oaks, CA, USA, 2013; ISBN 978-1-4833-1188-3.

104. Herrington, N.; Coogan, J. Q Methodology: An Overview. Res. Second. Teach. Educ. 2011, 1, $24-28$.

105. Banasick, S. Ken-Q Analysis; GitHub: San Francisco, CA, USA, 2016.

106. Praxis Group. Forging the Economic Future of the Duluth-Arrowhead Region; Mining Minnesota: Duluth, MN, USA, 2017. Available online: https://www.miningminnesota.com/economic-impact/future-of-iron-range.pdf (accessed on 8 December 2020).

107. Cole, M. Mining Jobs Pay a Lot More Than Tourism Jobs-And Are Not Seasonal. Available online: https://www.minnpost.com/letters/2017/05/mining-jobs-pay-lot-more-tourism-jobs-and-are-notseasonal/ (accessed on 16 January 2020).

108. Helmberger, M. Mining Minnesota Study Misfires on Tourism. Available online: https://www.minnpost. com/community-voices/2017/05/mining-minnesota-study-misfires-tourism/ (accessed on 16 January 2020).

109. Tuan, Y.-F. Perceptual and cultural geography: A commentary. Ann. Assoc. Am. Geogr. 2003, 93, 878-881. [CrossRef]

110. Nguyen, S.V.; Langston, N.; Wellstead, A.; Howlett, M. Mining the evidence: Public comments and evidence-based policymaking in the controversial Minnesota PolyMet mining project. Resour. Policy 2020, 69, 101842. [CrossRef]

Publisher's Note: MDPI stays neutral with regard to jurisdictional claims in published maps and institutional affiliations.

(C) 2020 by the authors. Licensee MDPI, Basel, Switzerland. This article is an open access article distributed under the terms and conditions of the Creative Commons Attribution (CC BY) license (http://creativecommons.org/licenses/by/4.0/). 